\title{
Fire severity effects on resprouting of subtropical dune thicket of the Cape Floristic Region
}

\author{
Tiaan Strydom $^{\text {Corresp., 1, } 2, \text { Tineke Kraaij }}{ }^{1,2}$, Mark Difford ${ }^{2}$, Richard M Cowling ${ }^{2}$ \\ 1 School of Natural Resource Management, Nelson Mandela University, George, Western Cape, South Africa \\ 2 African Centre for Coastal Palaeoscience, Nelson Mandela University, Port Elizabeth, Eastern Cape, South Africa \\ Corresponding Author: Tiaan Strydom \\ Email address: s213206781@mandela.ac.za
}

It has been hypothesised that high-intensity fires prevent fire-dependent fynbos from being replaced by fire-avoiding subtropical thicket on dune landscape of the Cape Floristic Region (CFR). Recent extensive fires provided an opportunity to test this hypothesis. We posit that (1) fire-related thicket shrub mortality would be size dependent, with smaller individuals suffering higher mortality than larger ones; and (2) that survival and resprouting vigour of thicket shrubs would be negatively correlated with fire severity. We assessed survival and resprouting vigour post-fire in relation to fire severity and pre-fire shrub size at two dune landscapes in the CFR. Fire severity was scored at the base of the shrub and categorised into four levels. Pre-fire size was quantified as an index of lignotuber diameter and stem count of each shrub. Resprouting vigour consisted of two variables; resprouting shoot count and resprouting canopy volume. A total of 29 species were surveyed. Post-fire survival of thicket was high (83-85\%). We found that smaller shrubs did have a lower probability of post-fire survival than larger individuals but could detect no consistent relationship between shrub mortality and fire severity. Fire severity had a positive effect on resprouting shoot count but a variable effect on resprouting volume. Pre-fire size was positively related to survival and both measures of resprouting vigour. We conclude that thicket is resilient to high-severity fires but may be vulnerable to frequent fires. Prescribed high-intensity fires in dune landscapes are unlikely to reduce the extent of thicket and promote fynbos expansion. 
1 Fire severity effects on resprouting of subtropical dune thicket of the Cape Floristic Region

2 Tiaan Strydom ${ }^{1,2}$, Tineke Kraaij ${ }^{1,2}$, Mark Difford ${ }^{2}$, Richard M. Cowling ${ }^{2}$

3

$4 \quad{ }^{1}$ School of Natural Resource Management, Nelson Mandela University, Private Bag X6531, 5 George, Western Cape 6530, South Africa

$6{ }^{2}$ African Centre for Coastal Palaeoscience, Nelson Mandela University, PO Box 77000, Port

7 Elizabeth, Eastern Cape 6031, South Africa

$8{ }^{*}$ Corresponding author: tiaanstrydom.nature@gmail.com , +2761 495 2784, George, Western

9 Cape 6530, South Africa

10

${ }^{1}$ Tiaan Strydom https://orcid.org/000-0002-3714-0483

${ }^{1}$ Tineke Kraaij http://orcid.org/0000-0002-8891-2869

${ }^{2}$ Richard M. Cowling https://orchid.org/0000-0003-3514-2685

\section{Abstract}

It has been hypothesised that high-intensity fires prevent fire-dependent fynbos from being replaced by fire-avoiding subtropical thicket on dune landscape of the Cape Floristic Region (CFR). Recent extensive fires provided an opportunity to test this hypothesis. We posit that (1) fire-related thicket shrub mortality would be size dependent, with smaller individuals suffering higher mortality than larger ones; and (2) that survival and resprouting vigour of thicket shrubs would be negatively correlated with fire severity. We assessed survival and resprouting vigour post-fire in relation to fire severity and pre-fire shrub size at two dune landscapes in the CFR. Fire severity was scored at the base of the shrub and categorised into four levels. Pre-fire size was quantified as an index of lignotuber diameter and stem count of each shrub. Resprouting vigour consisted of two variables; resprouting shoot count and resprouting canopy volume. A total of 29 species were surveyed. Post-fire survival of thicket was high (83-85\%). We found that smaller shrubs did have a lower probability of post-fire survival than larger individuals but could detect no consistent relationship between shrub mortality and fire severity. Fire severity had a 
29 positive effect on resprouting shoot count but a variable effect on resprouting volume. Pre-fire 30 size was positively related to survival and both measures of resprouting vigour. We conclude that thicket is resilient to high-severity fires but may be vulnerable to frequent fires. Prescribed highintensity fires in dune landscapes are unlikely to reduce the extent of thicket and promote fynbos expansion.

\section{Acknowledgements}

We thank Zanri Schoeman, Samukelisiwe Msweli and Thomas Vos whom assisted with field surveys. We thank Adriaan Grobelaar for producing a map of the study sites. Rainfall and fire danger weather data were supplied by the South African Weather Service. Reviewers provided useful suggestions that led to improvements to the manuscript.

\section{Introduction}

An understanding of the ecological determinants of the boundaries between vegetation formations (biomes) is central to managing and conserving biodiversity (Cowling and Potts 2015; Hansen and di Castri 1992). South Africa is rich in biomes, the distributions of which are under a wide range of environmental and biotic controls (Bond et al. 2003; Rutherford and Westfall 2016). A particularly interesting case is the co-occurrence of both fire-dependent (require fire for persistence) and fire-avoiding (occurring in areas were fire seldom occur) biomes in the same mesoclimate and geology, and the extent to which fire or other factors determine that co-occurrence. Notable amongst these cases is the stable co-occurrence of firedependent fynbos and fire-avoiding forest and thicket in South Africa's Cape Floristic Region (CFR) (Cowling et al. 1997; Cramer et al. 2019; Geldenhuys 1994). The persistence of fynbos species depends on regular, crown fires which stimulate recruitment from persistent soil- and canopy-stored seed banks of relatively short-lived species (Pierce and Cowling 1991) forest and thicket, on the other hand, have predominantly short-lived, bird-dispersed diaspores which produce shade tolerant seedlings that require long fire-free intervals for recruitment into fynbos (Cowling et al. 1997; Manders and Richardson 1992). Co-occurrence of these biomes has been attributed to differences in fire regimes (Bond et al. 2003; Geldenhuys 1994; Manders and Richardson 1992; Pierce and Cowling 1991; Vlok et al. 2003), soil nutrients (Coetsee et al. 2015; Cramer et al. 2019; Manders and Richardson 1992), soil moisture (Manders and Richardson 1992) and other disturbances such as wind or large herbivores (Vlok and Euston-Brown 2002). 
59

60

61

62

63

64

The Holocene dunes of the Cape Floristic Region comprise a mosaic of dune fynbos (hereafter fynbos) and subtropical dune thicket (hereafter thicket) which co-occur in roughly equal proportions throughout the extent of this small and fragmented coastal landscape (Pierce and Cowling 1991; Tinley 1985; Vlok et al. 2003). Casual observations suggest that most thicket species are capable of resprouting from basal and aerial bud banks but the extent to which resprouting vigour varies with fire severity (sensu Keeley 2009) and shrub size is unknown. It has been hypothesized that fire intensity and frequency are the primary determinants of the cooccurrence and relative abundances in dune landscapes of these two biomes; occasional highintensity burns destroy mature thicket shrubs whereas frequent fires kill young thicket plants that have established in fynbos (Cowling et al. 1997; Cowling and Potts 2015; Vlok et al. 2003). However, other than some observations of post-fire regeneration in fynbos (Cowling and Pierce 1988), there has been little research on the fire ecology of dune thicket communities and nothing is known about the response of thicket shrubs to different fire regimes. Generally, the fine fynbos fuels are more flammable and burn at higher intensities than coarser thicket fuels (Burger and Bond 2015; Calitz et al. 2015), except under extreme conditions when thicket can burn at intensities that may exceed those in fynbos (Kraaij et al. 2018). In fynbos ecosystems, highintensity fires promote good regeneration of obligate reseeding (non-sprouting) species (Bond et al. 1990), whereas low-intensity fires benefit resprouting species (Vlok and Yeaton 1999; Vlok and Yeaton 2000). Under natural conditions fire return intervals in dune landscapes are thought to be anything from 16-26 years in fynbos and 50 years or more in unbroken stands of thicket (Cowling et al. 1997; Kraaij et al. 2013; Cowling and Potts 2015).

An important aim of our study was to provide recommendations for the ecological management of fire in dune landscapes that will ensure co-occurrence of its two component biomes. Fire suppression has long been practised in dune landscapes in order to protect assets (particularly coastal resort developments and exotic timber plantations), which has resulted in near absence of fires for decades and the accumulation of large fuel loads (Cowling et al. 1997; Kraaij et al. 2011). Prescribed burning for ecological purposes is difficult to implement as fires in longunburnt vegetation pose significant safety risks (van Wilgen 2009). Should managers implement frequent, low-intensity fires to reduce fuel accumulation or should they implement infrequent high-intensity fires to reduce thicket extent and encroachment? Recent extensive fires along the southeastern CFR coast (Kraaij et al. 2018) presented an opportunity to assess the response of 
90

91

92

thicket shrubs to varying fire severity. In particular, we set out to test the following hypotheses: (1) fire-related thicket shrub mortality would be size dependent, with smaller individuals suffering higher mortality than larger ones; and (2) that survival and resprouting vigour of thicket shrubs would be negatively correlated with fire severity. We tested these hypotheses by surveying post-fire survival and resprouting vigour of thicket shrubs in relation to fire severity and pre-fire shrub size. We surveyed two sites (176 km apart) that burnt at different times (Jan 2016 and Jun 2017) and under different weather and climatic conditions. This provided us with a wide range of fire intensities (within and between fires) that allowed us to get a sense of the geographic generality of any findings.

\section{Materials and methods}

\section{Study area}

The study area comprises of two dune landscape sites (hereafter 'sites') along the southeastern CFR coast of South Africa, where fires have occurred in recent years, i.e. at Cape St Francis $\left(34^{\circ} .19028 \mathrm{~S} 24^{\circ} .82112 \mathrm{E}\right)$ and Knysna $\left(34^{\circ}, 24046 \mathrm{~S} 22^{\circ}, 50438 \mathrm{E}\right)$ (Fig. 1). Permission was obtained from CapeNature (permit number CN35-59-4006) to work on land under their management. The Cape St Francis fire was 1000 ha in extent, occurred in summer (25 Jan- 01 Feb 2016), and followed a year of average rainfall (Fig. S1). The mean fire danger rating during the month preceding the fire was dangerous, whereas those on the days of the fire varied from moderate to extremely dangerous (Table S1). The Knysna fire was 15000 ha in extent (of which approximately 2500 ha comprised Holocene dunes with fynbos thicket mosaic vegetation), occurred in winter (06-11 June 2017), and followed the worst 18-month drought in recorded history (Kraaij et al. 2018; Fig S1). The mean fire danger rating during the month preceding the fire was dangerous, whereas those on the days of the fire varied from moderate to extremely dangerous (Table S1). The pre-fire age of the vegetation was unknown at both Cape St Francis and Knysna but was deemed to be in excess of 40 years at both sites. The soils at these sites comprise deep, well-drained, calcareous sands associated with hairpin (east-west-trending) dunes of terminal Pleistocene to Holocene origin (Tinley 1985). Annual precipitation varies between 600 and $900 \mathrm{~mm}$ and occurs throughout the year with slight peaks in autumn and spring (Rebelo et al. 2006). Fire may occur at any time of the year with fire danger weather peaking in the dry 
120 summer months and in autumn and winter when warm and dry katabatic or "berg" winds are

121 common (Kraaij et al. 2013a).

122 According to the national classification, the vegetation of the area is Southern Cape Dune

123 Fynbos (Rebelo et al. 2006). In particular, the calcareous dunes of the CFR's southeast coast

124 support mosaics of fynbos with floristic affinities to the warm-temperate CFR and thicket of

125 subtropical affinity (Pierce and Cowling 1991; Vlok et al. 2003) (Fig. S2). In areas protected

126 from fire, such as narrow dune valleys with steep-sided walls, dune thicket reaches forest stature

127 and includes several species that are rare in fire-exposed thicket e.g. Apodytes dimidiata

128 (Icacinaceae), Chionathus foveolatus (Oleaceae), Zanthoxylum capense (Rutaceae) (Cowling et

129 al. 1997; Van der Merwe 1976). Thicket is dominated by tall (2-5 m), mesophyllous shrubs that

130 form a dense, closed and often impenetrable shrubland (Vlok et al. 2003) and is regarded as a

131 fire-avoiding biome (Cowling et al. 2005; Linder 2005). Fynbos, on the other hand, seldom

132 exceeds $2 \mathrm{~m}$ in height and is a much more open community. Thicket shrubs produce short-lived,

133 bird-dispersed fruits and recruitment typically occurs in shaded microsites during the inter-fire

134 stage (Cowling et al. 1997). Most dune thicket shrubs appear capable of basal sprouting as multi-

135 stemmed individuals are common (Kruger et al. 1997; Midgley and Cowling 1993); sprouting

136 from aerial shoots is also a feature of many species (Tiaan Strydom, pers. obs.). All our sample

137 sites were located in burnt thicket, but some sites did include populations of forest species,

138 especially those of taller $(>5 \mathrm{~m})$ stature.

\section{Data collection}

141 Field surveys were undertaken during April 2018 (28 months post-fire) at Cape St Francis and 142 during August 2018 (14 months post-fire) at Knysna. Belt transects $(\mathrm{n}=51)$ of $50 \mathrm{~m} \times 5 \mathrm{~m}$ were

143 positioned within the burnt areas to incorporate various fire intensities and the thicket shrub species composition and abundance that were representative of the area. We sampled $90 \%$ of the species of canopy forming thicket shrubs that occur at the Knysna site and all such shrubs at the

146 Cape St Francis site. Plant identification was based on the leaves of the resprouts of live individuals and the shrub architecture and bark texture of individuals killed by fire. Within transects, we measured shrubs with a lignotuber diameter of $>5 \mathrm{~cm}$ to avoid missing small shrubs that may have burnt away in, or decayed after, the fire. An individual shrub was considered to be 
150 all stems radiating out from a central lignotuber, with these stems no further than $5 \mathrm{~cm}$ away

151 from the lignotuber (Marais et al. 2014). Measurements included the fire severity (Firebase) an

152 individual shrub has experienced, its pre-fire dimensions (that of the burnt skeleton) and post-fire

153 resprouting vigour. Fire severity was assessed by subjectively scoring the extent of damage to

154 the base of the stem (at 0-50 cm from the ground) on each shrub as follows: $1=$ low (bark burnt

155 black, but intact); 2 = medium (considerable fire damage to bark); 3 = high (bark destroyed by

156 fire and considerable damage to the wood); 4 = extreme (extreme damage to the wood, which is

157 partially consumed by fire) (Fig. S3). We also scored fire severity in terms of damage to the

158 canopy and size of remaining material after established methods of Moreno and Oechel (1991)

159 and Marais et al. (2014) and found that fire severity scores at the base and canopy levels were

160 significantly correlated $\left(r_{s}=0.77 ; p<0.001\right)$. We therefore only used fire severity at the base for

161 subsequent analyses as this measure is most relevant to plants, such as our study species, that

162 display basal sprouting. Pre-fire dimensions (regarded as proxies for pre-fire biomass) were

163 assessed by measuring the lignotuber diameter at the base and counting the number of pre-fire

164 stems as a measure of stored reserves, available bud bank and age (Marais et al. 2014). Post-fire

165 resprouting vigour was assessed in terms of (i) resprouting canopy diameter (the mean of the

166 longest and shortest diameter), (ii) the number of shoots resprouting from the shrub base (no

167 further than $5 \mathrm{~cm}$ away from the lignotuber); (iii) length $(\mathrm{cm})$ of the longest resprouting shoot,

168 and (iv) variability in the lengths of resprouting shoots by allocating a subjective score of low

169 variability (all shoots approximately the same length), medium variability (noticeable difference

170 in shoot lengths) or high variability (high variability in shoot lengths). We aimed to survey a

171 minimum of 30 individuals of each species, but this could not be achieved for all species as some

172 species were naturally rare.

\section{Data analysis}

175 The unit of replication comprised of individual shrubs (species were assessed jointly and

176 included as a random factor); sample sizes at Cape St Francis (519 shrubs across 31 transects)

177 and Knysna (593 shrubs across 20 transects) were comparable. We compared the median fire

178 severity score between the two sites using a Mann-Whitney $U$ test. We assessed survival of all

179 thicket shrubs from both study sites using a logistic regression model (binomial family, logit 
180 link) from the open source $R$ software (version 1.1.383) (R Development Core Team 2013) (R 181 code S1; Table S2). As predictors of survival we included fire severity (an ordered factor with 182 four levels), an index of pre-fire size (see below), site (a two-level factor), and all interactions 183 between the predictors. Pre-fire shoot count and pre-fire lignotuber diameter (both measures of 184 pre-fire size) were highly correlated and, therefore, were combined into an index of pre-fire size 185 by calculating as the sum of pre-fire stem count and pre-fire lignotuber diameter, each of which was transformed to range between 0 and 1 (to weight both measures equally). We tested for collinearity between fire severity and pre-fire size, but this relationship was weak (Fig. S4) and both factors were therefore retained in analyses. We employed stepwise selection to identify the best subset model using AIC as the model selection criterion (Akaike 1974; Symonds and Moussalli, 2011). Factors included in the final selected model were fire severity, pre-fire size, site, and the two-way interaction between fire severity and pre-fire size.

192

193

194

195

196

197

198

199

200

201

202

203

204

205

206

207

We assessed the number of resprouting shoots (an integer-valued count variable) occurring at the shrub base of all thicket shrubs using the Delaporte distribution for count data. This is a threeparameter distribution available in the gamlss (generalized additive models for location, scale and shape) contributed package for R (Stasinopoulos et al. 2017). We modelled the mean using the default logarithmic link, and dispersion and skewness using null models (logarithmic links). As predictors, we included fire severity (a four-level ordered factor), pre-fire size (the index detailed above), site (a two-level factor), and all interactions as fixed factors (Code S2; Table S2). We employed stepwise selection to identify the best subset model using AIC as the model selection criterion (Akaike 1974; Symonds and Moussalli 2011). The full model was selected as the final model.

We used a two-parameter Weibull distribution (Stasinopoulos et al. 2017) to assess the resprouting volume of all thicket shrubs in relation to fire severity (an order factor), pre-fire size (the index detailed above), site (a two-level factor), and all interactions as fixed factors (R code $\mathrm{S} 3$; Table S2). For the response variable, resprouting volume, we estimated canopy volume as the volume of a cone (Volume $\left.=\frac{1}{3} \pi r^{2} h\right)$, where $r$ represents the mean of the long and short diameter of the resprouting canopy divided by two, and $h$ represents the length of the longest resprouting shoot. We adjusted the length of the longest resprouting shoot by a factor of 0.75 for a shrub that displayed medium variability in resprouting shoot length and by a factor of 0.50 for 
210 a shrub displaying high variability in shoot length, and no adjustment for a shrub displaying low

211 variability in shoot length. The model was fitted using the default logarithmic link function,

212 coupled with the default null model for dispersion, and fitted using a logarithmic link function.

213 We used AIC-based stepwise selection to identify the best subset model (Akaike 1974; Symonds

214 and Moussalli 2011). Factors included in the final selected model were fire severity, pre-fire size, 215 site, and the interactions between fire severity and site, and pre-fire size and site.

216

217

\section{Results}

218

The median ( $\pm \mathrm{SE})$ fire severity score was significantly higher $\left(Z_{1.92}=10.54, P<0.000\right)$ at Cape

St Francis $(4 \pm 0.9)$ than at Knysna $(3 \pm 0.9)$. A total of 29 species were surveyed, three of which occurred only at Cape St Francis and 12 of which occurred only at Knysna (Table 1). All species surveyed were capable of resprouting after fire, with survival being very high at Cape St Francis (85\% of individual shrubs) and Knysna (83\%) (Table 1). Resprouting was virtually exclusively from the shrub bases, but a few species showed epicormic resprouting when fire severity in the canopy was low, including Chionanthus foveolatus (Oleaceae), Pterocelastrus tricuspidatus (Celastraceae), Sideroxylon inerme (Sapotaceae) and Tarchonanthus littoralis (Asteraceae) but we suspect all the species would resprout epicormically after low severity fire. Species showing lowest survival were Psydrax obovata (Rubiaceae), Scolopia zeyheri (Flacourtiaceae), Apodytes dimidiata (Icacinaceae), Gymnosporia buxifolia (Celastraceae), Sideroxylon inerme and Chionanthus foveolatus. All the final models assessing the effects on survival, post-fire resprouting shoot count and resprouting volume of fire severity, pre-fire size, site, and their interactions, explained only small proportions of the overall deviance $\left(r^{2}=0.05,0.09\right.$ and 0.19 , respectively; Table 2, 3,4), suggesting that most variation was not accounted for by the factors investigated. Amongst these factors, pre-fire size was the primary determinant of the post-fire response, showing consistently positive effects on survival, post-fire resprouting shoot count and post-fire resprouting volume (Fig. 2-4; Tables 2-4). Fire severity and site had comparatively minor effects (in terms of the amount of deviance explained, Table 2,3,4) and often interacted with each other or with pre-fire size. Shrubs generally survived better and resprouted more vigorously at Cape St Francis than they did at Knysna, despite fire severity being higher at Cape 
240

241

242

243

244

245

246

247

248

249

250

251

252

253

254

255

256

257

258

259

260

261

262

263

264

265

266

267

268

small (explaining little deviance relative to the other factors; Table 2, 3, 4) but was more important on post-fire resprouting volume (explaining a similar amount of deviance to fire severity). Fire severity interacted with pre-fire size in its effect on survival (Table 2), with high fire severity possibly having more pronounced negative effects on the survival of large shrubs (Fig. 2). Fire severity had a generally positive effect on post-fire resprouting shoot count and interacted with site and pre-fire size in complex ways (all second and third-order interactions were significant) (Fig. 3, Table 3). Site interacted with pre-fire size and with fire severity in its effects on post-fire resprouting volume (Table 4). The positive effect of pre-fire size on post-fire resprouting volume was more pronounced at Knysna than it was at Cape St Francis, while fire severity had opposing effects on post-fire resprouting volume at the two sites (Fig. 4).

\section{Discussion}

\section{Importance of fire in maintaining boundaries between thicket and fynbos}

Contrary to tacit understanding (Cowling et al. 1997; Cowling and Potts 2015; Vlok et al. 2003), our results showed that fire severity has only minor or inconsistent (among sites and shrub size classes) effects on the survival and resprouting vigour of thicket shrubs. We assessed the community level response of thicket to fire, by considering species as a random factor and including shrub species composition that was representative of the communities at our study sites. The fires assessed in the current study were of high to extreme severity (based on our assessments and other evidence, Kraaij et al. 2018; Swana 2016) and despite this, survival of thicket shrubs was remarkably high. Only the very largest of shrubs (basal diameter 80-100 cm; Cassine peragua, Pterocelastrus tricuspidatus, Sideroxylon inerme) exhibited an increased susceptibility to mortality at the highest fire intensities but the probability of survival in these large shrubs was still above $80 \%$ (Fig. 2). Equally the lowest survival probability (i.e. under high fire severity) exhibited by the smallest shrubs was $60 \%$. Bud protection and bark production (Clarke et al. 2013; Charles-Dominique et al. 2015) (which was not investigated) may be an important factor explaining variation in survival and resprouting vigour of thicket shrubs post-fire as this was shown to be important in savanna trees (Charles-Dominique et al. 2015). Fire severity is, therefore, not deemed a major driver of mortality of thicket shrubs and hence is 
269 unlikely to play an important role in maintaining the boundaries and stable co-occurrence of

270 thicket and fynbos in coastal dune landscapes.

271 The pre-fire size of shrubs was the most significant predictor of post-fire survival and

272 resprouting vigour of thicket, with bigger shrubs (stem diameter $>10 \mathrm{~cm}$ ) showing improved

273 survival and resprouting vigour than smaller shrubs (stem diameter $\leq 10 \mathrm{~cm}$ ). This suggest that

274 longer fire cycles would enable thicket shrubs to achieve sizes that conferred fire survival and

275 thus promote thicket development. In many fire-prone ecosystems increased fire frequency has

276 significant effects on vegetation structure and composition (Hoffmann and Solbrig 2003; Kraaij

277 et al. 2013b; Roques et al. 2001; van Wilgen et al. 1994), through keeping woody plants small

278 and therefore vulnerable to fire (Bond and Midgley 2001). In savannas, very short (1-6 year) fire

279 return intervals (Govender et al. 2006) reduce the tree-grass ratio by supressing post-fire

280 recovery of some woody species despite the ability to resprout (Bond and Midgley 2001;

281 Hoffmann and Solbrig 2003; Roques et al. 2001; Smit et al. 2010). For instance, in southeastern

282 Australian savanna where fire is deemed an important factor to maintain tree-grass co-existence,

283 only 20-30\% of small trees survived high intensity fire (Morrison and Renwick 2000). In our

284 study, smaller thicket shrubs generally showed poorer survival and resprouting vigour than larger

285 shrubs, although the average post-fire survival of small thicket shrubs was high ( $>80 \%)$ across

286 fire severities. This suggests that frequent fires would maintain smaller thicket shrubs that are

287 more prone to suffer supressed recovery potential than larger shrubs, but that the effects of

288 frequent fires may be limited.

289

290 In our study, site had a relatively minor effect on the post-fire response in terms of survival and

291 number of resprouting shoots, but a more important effect on resprouting canopy volume. The

292 latter may be primarily explained by the post-fire age difference at the time of surveying between

293 the two sites. Cape St Francis was surveyed at 38 months post-fire as opposed to 14 months post-

294 fire at Knysna, which meant that resprouting canopies would have been larger at the time of

295 surveying at Cape St Francis. Given the difference in post-fire age between the two sites, apical

296 dominance (Aarssen 1995) could also have had disparate effects at the two sites, supported by

297 our finding that the post-fire shoot count was generally lower at Cape St Francis than at Knysna

298 (Fig. 3). Another potential contributing factor may be bud tissue damage after high severity fire,

299 resulting in less carbohydrate reserves available to resprouting shoots and thus reducing 
300 resprouting vigour (Clarke et al. 2013). The mean fire severity score at Cape St Francis was

301 higher than at Knysna, suggesting that bud tissue damage should have been more extensive at the 302 former, yet shrubs at Cape St Francis displayed greater resprouting volume. Potential effects of

303 pre-fire reserves are however clouded by disparate post-fire ages at the time of measurement. We 304 thus contend that a combination of post-fire age and apical dominance largely explains the 305 difference in resprouting vigour between the two sites. Discrepancies in post-fire rainfall are 306 307 unlikely to have played a large role as both sites received somewhat less than the long-term mean annual rainfall in the post-fire period (Fig. S1). Resprouting shrubs are furthermore known to be less sensitive to drought conditions after fire than reseeding shrubs (Zeppel et al. 2015). However, the severe drought that prevailed at the Knysna site pre-fire (Kraaij et al. 2018; Fig. S1) could have contributed to depressed resprouting vigour compared to that at Cape St Francis. Since site did not have strong or consistent effects on the post-fire response, this suggests that the observed vigour in post-fire recovery of thicket shrubs is likely to be generic across fires of varying intensity, season and size. Detailed investigations at species level were beyond the scope of this study, but survival rates and resprouting vigour varied considerably among species (Table 1). Jointly, the factors investigated in our models did not explain a large part of the variation in the post-fire response of thicket shrubs. We therefore suggest that species, shrub architecture, and local site effects warrant further investigation.

\section{Other factors that may sustain thicket-fynbos boundaries}

Various other factors may potentially be of importance in determining the boundaries between thicket and fynbos in dune landscapes. Cramer et al. (2019) showed that differences in soil nutrients largely account for the boundaries between forest and fynbos. Here fire and soil nutrients interact, with frequent fires killing forest seedlings and consuming the organic components of mulch-rich top-soils, thereby preventing nutrient-demanding forest species from invading nutrient-poor fynbos soils maintained by recurrent fire (Coetsee et al. 2015; Cramer et al. 2019; Manders and Richardson 1992). On the contrary, unlike the case on other substrata (Cowling and Potts 2015), soil nutrient levels (including organic carbon and nitrogen) in our dune system are comparable between thicket and fynbos (Table S3; Cowling 1984). We speculate that soil moisture may be of greater importance in explaining the boundaries between these two biomes in dune landscapes. Manders and Richardson (1992) suggested that soil 
330 nutrients together with soil moisture are important in sustaining the boundaries between forest

331 and fynbos. Thicket grows predominantly at the base of dunes and in well-drained dune swales

332 (Cowling 1984; De Villiers et al. 2005); moisture levels in these sites are invariably higher than

333 dune crests and the upper slopes (Maun 2009; Tinley 1985) where fynbos dominates. Although a

334 subset of thicket shrubs does grow in these drier sites, they remain sparse, stunted and sub-

335 dominant to the fynbos component (Cowling 1984).

336 Megaherbivores such as elephant and black rhinoceros browsed in dune landscapes prior to their

337 extirpation during colonial times (Boshoff and Kerley 2001; De Villiers et al. 2005; Radloff

338 2008). While these herbivores do not collapse the structure of thicket where it exists in extensive

339 patches (Cowling et al. 2009; Radloff 2008), their impacts where thicket forms a mosaic with

340 fire-prone shrublands, have not been studied. They may have opened up thicket canopies,

341 enabling shade intolerant and highly flammable fynbos shrubs to invade. However, as we have

342 shown here, most thicket species' post-fire survival is weakly influenced by fire severity.

343 Furthermore, megaherbivore impacts would not explain the absence of thicket from steep dunes

344 slopes which would have been avoided by these bulky browsers (Cowling et al. 2009).

\section{Management implications}

346 Our study demonstrated that all the thicket shrub species surveyed are capable of surviving fire

347 and, moreover, fire severity had an unexpected effect on resprouting vigour in the form of

348 increased number of resprouting shoots. Therefore, high intensity prescribed burning of dune

349 landscapes does not offer an effective means of limiting thicket shrub encroachment and

350 densification in fynbos. Although thicket does invade fynbos when the conditions are suitable

351 (Cowling et al. 1997), we suspect it would not invade all of the fynbos due to other drivers,

352 principally soil moisture availability, that maintain the boundaries between these two biomes.

353 However, frequent fires may prevent the encroachment of thicket juveniles into fynbos, owing to

354 the greater vulnerability of small shrubs to fire. Most recruitment of thicket individuals into

355 fynbos is via ramets (Midgley and Cowling 1993) that likely originate from well-established

356 plants in mature thicket clumps (Cowling 1982). The extent to which the development of these

357 ramets into taller individuals that can overtop fynbos is controlled by fire or resource availability

358 is unknown. Nonetheless, it is clear from our study that high-intensity fires are not an effective

359 tool for limiting thicket extent in the dune landscapes of the southeastern CFR. This is good 
360 news for managers, since these fires are difficult to control and thus represent a risk to

361 infrastructure. Instead, we recommend that frequent (5-10 year intervals), medium intensity

362 burns be explored as a potential means to prevent thicket encroaching into fynbos areas and

363 facilitate persistence of fire-dependent fynbos communities. In contrast to thicket which we have

364 shown to comprise virtually exclusively of resprouting shrub species, a large component (38\%)

365 of dune fynbos shrub species are non-sprouters (obligate reseeders) while the remainder are

366 facultative resprouters (Cowling et al. 2019). Reseeding fynbos species require medium to high

367 intensity fires at intervals exceeding the juvenile period of obligate reseeders to recruit

368 prolifically after fire (Kraaij and van Wilgen 2014). While too frequent fires may prevent

369 seedling recruitment of slow-maturing obligate reseeders in mountain fynbos (Kraaij et al.

370 2013b), dune fynbos shrubs are short-lived with short juvenile periods (lifespan of 5-50 years;

371 Pierce and Cowling 1991). On these grounds and supported by the model predictions of Cowling

372 et al. (1997) we suggested a regime of frequent and medium intensity fires, although the impacts

373 of such a fire regime on dune fynbos-thicket dynamics require further research.

374

\section{Conclusion}

376 Our findings based on two distinct fire events confirm that fire severity is not an important

377 determinant of thicket shrub survival and ultimately does not offer a management tool to limit

378 thicket encroachment and densification into fynbos. However, pre-fire size of the thicket shrubs

379 had consistent positive effects on post-fire survival and resprouting vigour, with larger shrubs

380 being more resilient. We suggest there are many other factors that are of greater importance in

381 determining these biome boundaries in dune landscapes.

\section{References}

385 Aarssen LW (1995) Hypotheses for the evolution of apical dominance in plants: implications for 386 interpretations of overcompensation. Oikes 74(1):149-156

387 Akaike H (1974) A new look at the statistical model identification. In: Selected Papers of Hirotugu 
389 Bond WJ, Midgley GF, Woodward FI (2003) What controls South African vegetation - Climate or 390 fire? South African J Bot 69:79-91 . doi: 10.1016/S0254-6299(15)30362-8

391 Bond WJ, Midgley JJ (2001) Ecology of sprouting in woody plants: The persistence niche. Trends 392 Ecol Evol 16:45-51 . doi: 10.1016/S0169-5347(00)02033-4

393 Bond WJ, Roux D Le, Erntzen R (1990) Fire intensity and regeneration of myrmecochorous 394 Proteaceae. South African J Bot 56:326-330 . doi: 10.1016/S0254-6299(16)31060-2

395 Boshoff AF, Kerley GIH (2001) Potential distribution of the medium-to large-sized mammals in 396 the Cape Floristic Region, based on historical accounts and habitat requirements. African 397 Zool 36:246-273

398 Burger N, Bond WJ (2015) Flammability traits of Cape shrubland species with different post-fire 399 recruitment strategies. South African J Bot 101:40-48 . doi: 10.1016/j.sajb.2015.05.026

400 Calitz W, Potts AJ, Cowling RM (2015) Investigating species-level flammability across five 401 biomes in the Eastern Cape, South Africa. South African J Bot 101:32-39 . doi: $402 \quad 10.1016 /$ j.sajb.2015.07.005

403 Charles-Dominique T, Beckett H, Midgley GF, Bond WJ (2015) Bud protection: a key trait for $404 \quad$ species sorting in a forest-savanna mosaic. New Phytol 207:1052-1060 . doi:

$405 \quad 10.1111 /$ nph.13406

406 Clarke PJ, Lawes MJ, Midgley JJ, Lamont BB, Ojeda F, Burrows GE, Enright NJ, Knox JE (2013) 407 Resprouting as a key functional trait: how buds, protection and resources drive persitence 408 after fire. New Phytol 196:19-35 . doi:10.1111/nph.12001

409 Coetsee C, Bond WJ, Wigley BJ (2015) Forest and fynbos are alternative states on the same $410 \quad$ nutrient poor geological substrate. South African J Bot 101:57-65 . doi:

$411 \quad$ 10.1016/j.sajb.2014.11.007

412 Cowling RM (1984) A syntaxonomic and synecological study in the Humansdorp region of the 413 fynbos biome. Bothalia 15:175-228

414 Cowling RM, Kamineth A, Difford M, Campbell EE (2009) Contemporary and historical impacts 
415 of megaherbivores on the population structure of tree euphorbias in South African

$416 \quad$ subtropical thicket. Afr J Ecol 48:135-145

417 Cowling RM, Kirkwood D, Midgley JJ, Pierce SM (1997) Invasion and persistence of bird418 dispersed, subtropical thicket and forest species in fire-prone coastal fynbos. J Veg Sci $419 \quad 8: 475-488$

420 Cowling RM, Logie C, Brady J, Middleton M and Grobler BA 2019. Taxonomic, biological and 421 geographical traits of species in a coastal dune flora in the southeastern Cape Floristic 422 Region: regional and global comparisons. PeerJ 7:e733 DOI 10.7717/peerj.7336.

423 Cowling RM, Pierce SM (1988) Secondary succession in coastal dune fynbos: variation due to site 424 and disturbance. Vegetatio 76:131-139

425 Cowling RM, Potts AJ (2015) Climatic, edaphic and fire regime determinants of biome boundaries 426 in the eastern Cape Floristic Region. S Afr J Bot 101:73-81 . doi:

$427 \quad 10.1016 /$ j.sajb.2015.03.182

428 Cowling RM, Proche S, Vlok JHJ (2005) On the origin of southern African subtropical thicket 429 vegetation. 71:1-23 . doi: 10.1016/S0254-6299(15)30144-7

430 Cramer MD, Power SC, Belev A, Gillson L, Bond WJ, Hoffman MT, Hedin LO (2019) Are forest431 shrubland mosaics of the Cape Floristic Region an example of alternate stable states? 432 Ecography (Cop) 42:717-729 . doi: 10.1111/ecog.03860

433 De Villiers C, Driver A, Clark B, Euston-Brown D, Day L, Job N, Holmes P, Brownlie S, Rebelo T 434 (2005) Ecosystem guidelines for environmental assessment in the Western Cape. Fynbos 435 Forum. 32-35

436 Geldenhuys CJ (1994) Bergwind Fires and the Location Pattern of Forest Patches in the Southern 437 Cape Landscape, South Africa. J Biogeogr 21:49 . doi: 10.2307/2845603

438 Govender N, Trollope WSW, van Wilgen BW (2006) The effect of fire season, fire frequency, 439 rainfall and managment on fire intensity in savanna vegetation in South Africa. J Appl Ecol $440 \quad$ 43:748-758 . doi: 10.1111/j.1365-2664.2006.01184.x

441 Hansen A, di Castri F (1992) Landscape Boundaries: Consequences for Biotic Diversity and 
442 Ecological Flows. Springer-Verlag. New York

443 Hoffmann WA, Solbrig OT (2003) The role of topkill in the differential response of savanna woody 444 species to fire. For Ecol Manage 180:273-286 . doi: 10.1016/S0378-1127(02)00566-2

445 Keeley JE (2009) Fire intensity, fire severity and burn severity: a brief review and suggested usage. 446 IJWF 18: 116-126.

447 Kraaij T, Baard JA, Arndt J, Vhengani L, van Wilgen BW (2018) An assessment of climate, 448 weather, and fuel factors influencing a large, destructive wildfire in the Knysna region, 449 South Africa. Fire Ecol 14: . doi: 10.1186/s42408-018-0001-0

450 Kraaij T, Cowling RM, van Wilgen BW (2011) Past approaches and future challenges to the 451 management of fire and invasive alien plants in the new Garden Route National Park The 452 Garden Route mountain catchments. S Afr J Sci 107:1-11 . doi: 10.4102/sajs.v107i9/10.633 453 Kraaij T, Cowling RM, van Wilgen BW (2013a) Lightning and fire weather in eastern coastal 454 fynbos shrublands: Seasonality and long-term trends. Int J Wildl Fire 22:288-295 . doi: $455 \quad 10.1071 / \mathrm{WF} 11167$

456 Kraaij T, Cowling RM, van Wilgen BW, Schutte-Vlok A (2013b) Proteaceae juvenile periods and 457 post-fire recruitment as indicators of minimum fire return interval in eastern coastal fynbos. $458 \quad$ Appl Veg Sci 16:84-94 . doi: 10.1111/j.1654-109X.2012.01209.x

459 Kraaij T, van Wilgen BW (2014) Drivers, ecology, and management of fire in fynbos. In: Allsopp 460 N, Colville JF, Verboom GA (eds) Fynbos: ecology, evolution, and conservation of a 461 megadiverse region. Oxford University Press, Oxford, pp 47-72

462 Linder HP (2005) Evolution of diversity : the Cape flora. Trends Plant Sci 10:536-541 . doi: 463 10.1016/j.tplants.2005.09.006

464 Manders PT, Richardson DM (1992) Colonization of Cape fynbos communities by forest species. 465 For Ecol Manage 48:277-293 . doi: 10.1016/0378-1127(92)90150-8

466 Marais KE, Pratt RB, Jacobs SM, Jacobsen AL, Esler KJ (2014) Postfire regeneration of 467 468 resprouting mountain fynbos shrubs: Differentiating obligate resprouters and facultative seeders. Plant Ecol 215:195-208 . doi: 10.1007/s11258-013-0289-4 
469 Maun MA (2009) The biology of coastal sand dunes. Oxford University Press

470 Midgley JJ, Cowling RM (1993) Regeneration patterns in Cape subtropical transitional thicket;

471 Where are all the seedlings? S Afr J Bot 59:496-499 . doi: 10.1016/S0254-6299(16)30694$472 \quad 9$

473 Moreno JM, Oechel WC (1991) Fire intensity and herbivory effects on postfire resprouting of 474 Adenostoma fasciculatum in southern California chaparral. Oecologia 85:429-433

475 Morrison DA, Renwick JA (2000) Effects of variation in fire intensity on regeneration of co476 occurring species of small trees in the Sydney region. Aust J Bot 48:71-79 . doi:

$477 \quad 10.1071 /$ BT98054

478 Pierce SM, Cowling RM (1991) Disturbance regimes as determinants of seed banks in coastal dune 479 vegetation of the southeastern Cape. J Veg Sci 2:403-412 . doi: 10.2307/3235933

480 Radloff FGT (2008) The ecology of large herbivores native to the coastal lowlands of the fynbos 481 biome in the Western Cape. (Doctoral dissertation, Stellenbosch: Stellenbosch University)

482 Rebelo A, Boucher C, Helme N, Mucina L, Rutherford MC (2006) Fynbos Biome. In L Mucina 483 and MC Rutherford. Vegetation Map of South Africa, Lesotho and Swaziland. South

484 African National Biodiversity Institute. pp. 144-145

485 Roques KG, O'connor TG, Watkinson AR (2001) Dynamics of shrub encroachment in an African 486 savanna : relative influences of fire, herbivory, rainfall and density. J Appl Ecol 38:268$487 \quad 280$

488 Smit IP, Asner GP, Govender N, Kennedy-Browdoin T, Knapp, DE, Jacobson J (2010) Effects of 489 fire on woody vegetation structure in African savanna. Ecol Appl 20:1865-1875

490 Stasinopoulos DM, Rigby RA (2007) Generalized additive models for location scale and shape 491 (GAMLSS) in R. J Stat Softw 23:1-46

492 Swana A (2016) Disaster teams battling St Francis fire. In: Her. LIVE Online. 493 https://www.heraldlive.co.za/news/2016-01-24-disaster-teams-battling-st-francis-fire/. $494 \quad$ Accessed 15 Mar 2019

495 Symonds MRE, Moussalli A (2011) A brief guide to model selection, multimodel inference and 
496

model averaging in behavioural ecology using Akaike' $\mathrm{s}$ information criterion. Behav Ecol

497

Sociobiol 65:13-21 . doi: 10.1007/s00265-010-1037-6

498 Tinley KL (1985) Coastal dunes of South Africa. National Scientific Programmes Unit, CSIR, $499 \quad$ Pretoria

500 Van der Merwe CV (1976) Die plantekologiese aspekte en bestuursprobleme van die Goukamma501 Natuurreservaat. MSc tesis. Universiteit van Pretoria. Pretoria. Suid Africa

502 van Wilgen BW (2009) The evolution of fire and invasive alien plant management practices in 503 fynbos. S Afr J Sci 105:335-342

504 van Wilgen, B.W. and Forsyth, G.G. (1992). Regeneration strategies in fynbos plants and their 505 influence on the stability of community boundaries after fire. In B.W. van Wilgen, D.M.

506 Richardson, F.J. Kruger, and H.J. van Hensbergen, eds. Fire in South African mountain 507 fynbos: species, community and ecosystem response in Swartboskloof, Ecological Studies, 508 93, 55-80. Springer-Verlag, Heidelberg.

509 van Wilgen BW, Richardson DM, Seydack A (1994) Managing fynbos for biodiversity : constraints 510 and options in a fire-prone environment. S Afr J Sci 90:322-329

511 Vlok JHJ, Euston-Brown D (2002) The patterns within, and the ecological processes that sustain, 512 the subtropical thicket vegetation in the planning domain for the Subtropical Thicket 513 Ecosystem Planning (STEP) project. Unpublished report. Terretrial Ecology Unit, $514 \quad$ University of Port Elizab

515 Vlok JHJ, Euston-Brown DIW, Cowling RM (2003) Acocks' Valley Bushveld 50 years on: New 516 perspectives on the delimitation, characterisation and origin of subtropical thicket 517 vegetation. S Afr J Bot 69:27-51 . doi: 10.1016/S0254-6299(15)30358-6

518 Vlok JHJ, Yeaton RI (1999) The effect of overstorey proteas on plant species richness in South 519 African mountain fynbos. Divers Distrib 5:213-222

520 Vlok JHJ, Yeaton RI (2000) Competitive interactions between overstorey proteas and sprouting 521 understorey species in South African mountain fynbos. Divers Distrib 6:273-281

522 Vlok JHJ, Euston-Brown DIW, Wolf T (2008) A vegetation map for the Garden Route Initiative. 
523 Unpublished 1:50 000 maps and report. CAPE task team, South African National Parks, $524 \quad$ Knysna

525 Zeppel MJ, Harrison SP, Adams HD, Kelley DI, Li G, Tissue DT, Dawson TE, Fensham R, 526 Medlyn BE, Palmer A, West AG (2015) Drought and resprouting plants. New Phytol 206 $527 \quad(2): 583-589$

528 


\section{Figure 1}

The two study sites, Knysna and Cape St Francis, that burnt and the extent of Holocene dunes along the southeast coast of the Cape Floristic Region.

The two smaller maps show the extent (coloured in red) of the Jun 2017 fires at Knysna and Jan 2016 fire at Cape St Francis. Imagery source: Estri, DigitalGlobe, GeoEye, Earthstar Geographics, CNES/Airbus DS, USDA, USGS, AeroGRID, IGN. Distribution data for Holocene dunes were derived from the Council for Geoscience 1:250,000 geological database. 


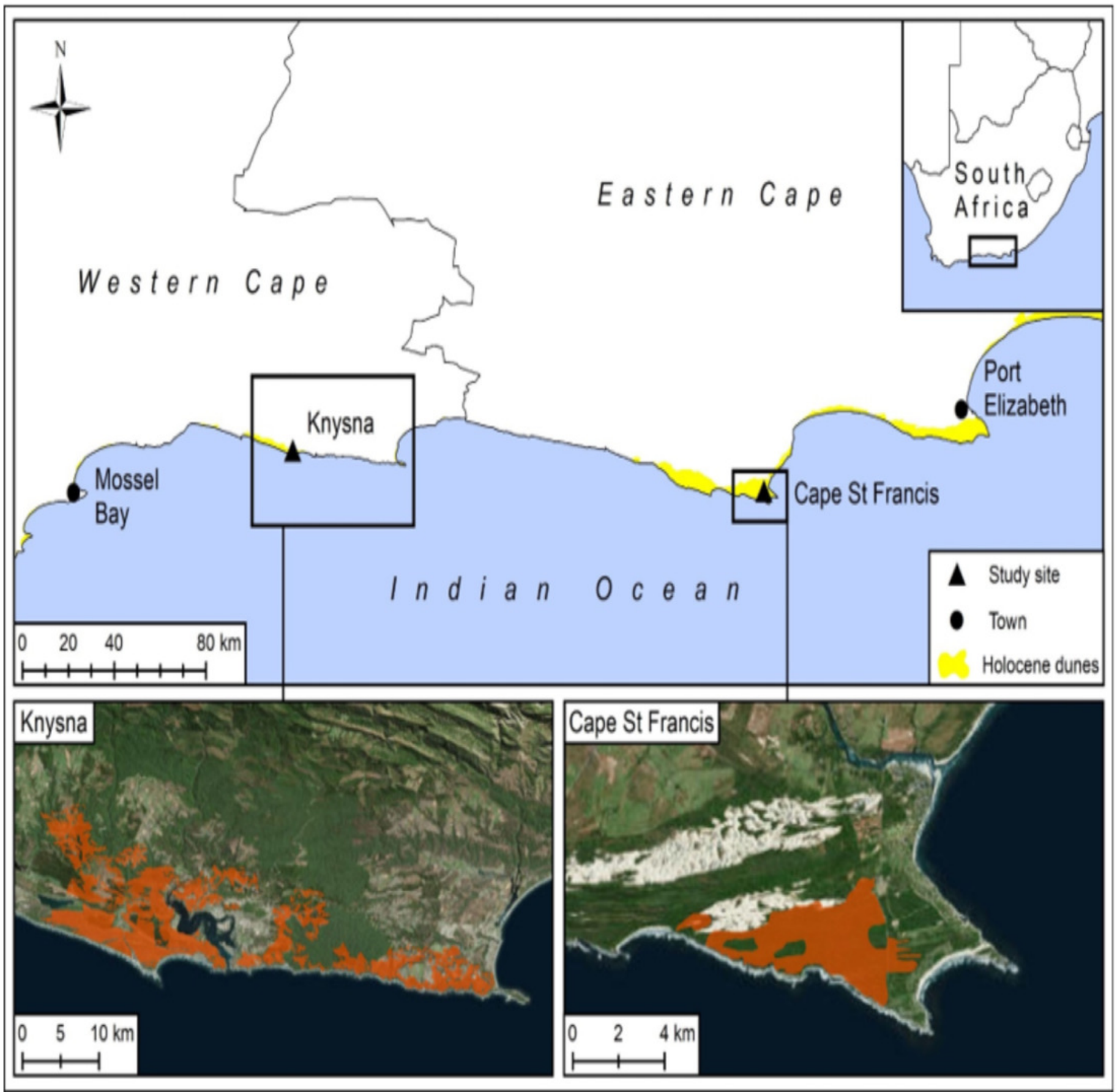


Figure 2

Predicted probability of post-fire survival of dune thicket shrubs in relation to the interaction between fire severity and pre-fire shrub size.

Fire severity was scored at the base of each shrub; Firebase (A) 1, low; (B) 2, medium; (C) 3, high; (D) 4, extreme. Pre-fire shrub size is an index (Prefiresize; see Methods for details). The output of the logistic regression model that was used to calculate the effects is given in Table 2. 


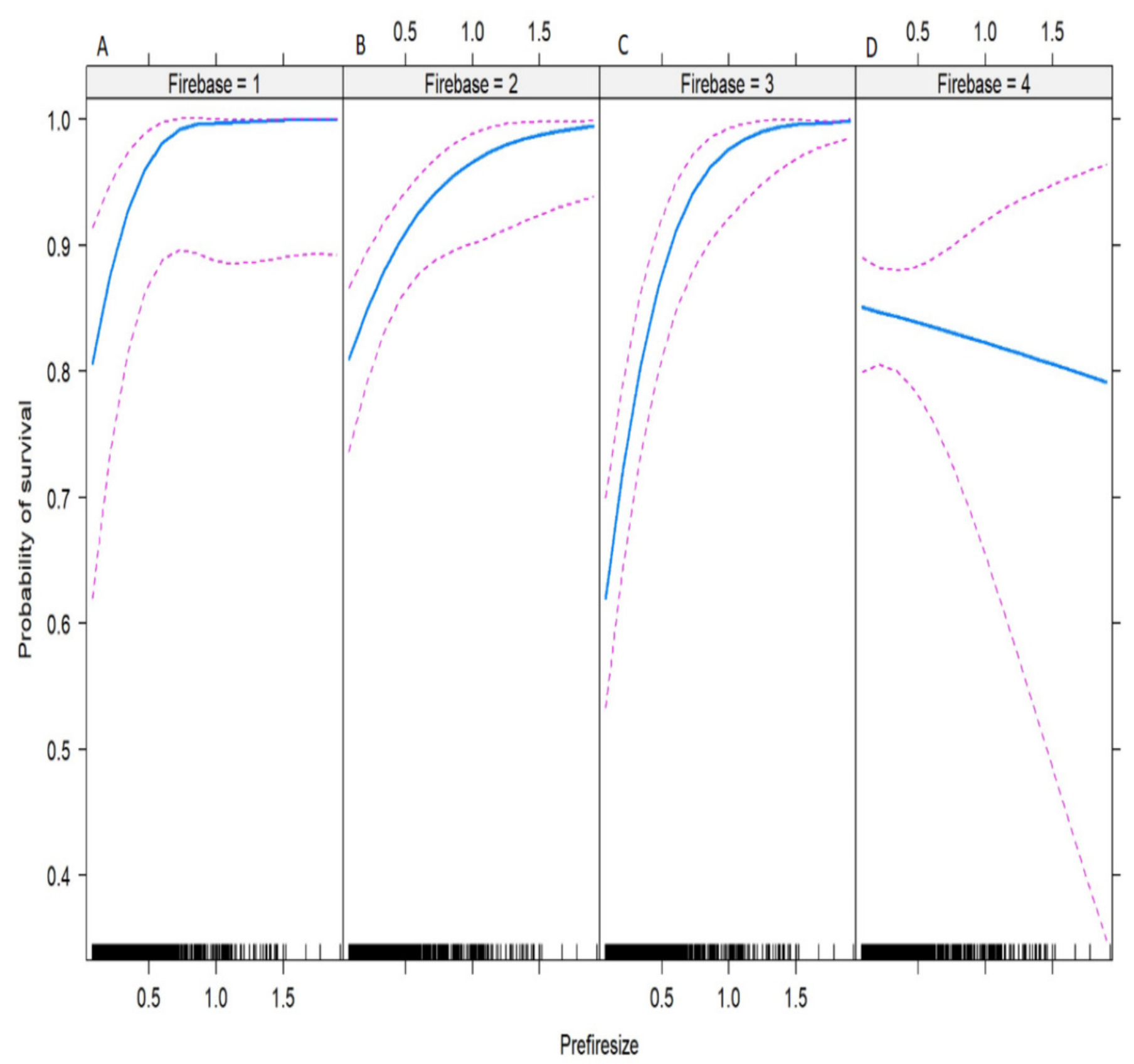




\section{Figure 3}

Predicted effects of the interaction between fire severity, pre-fire shrub size and site on the logarithm of the post-fire shoot count of dune thicket shrubs.

Fire severity was scored the base of each shrub (Firebase $=1$, low; 2, medium; 3, high; 4, extreme). Pre-fire shrub size is an index (Prefiresize; see Methods for details). Sites were (AD) CSF, Cape St Francis; and (E-H) KNS, Knysna. The output of the Delaporte count model that was used to calculate the effects is given in Table 3. 


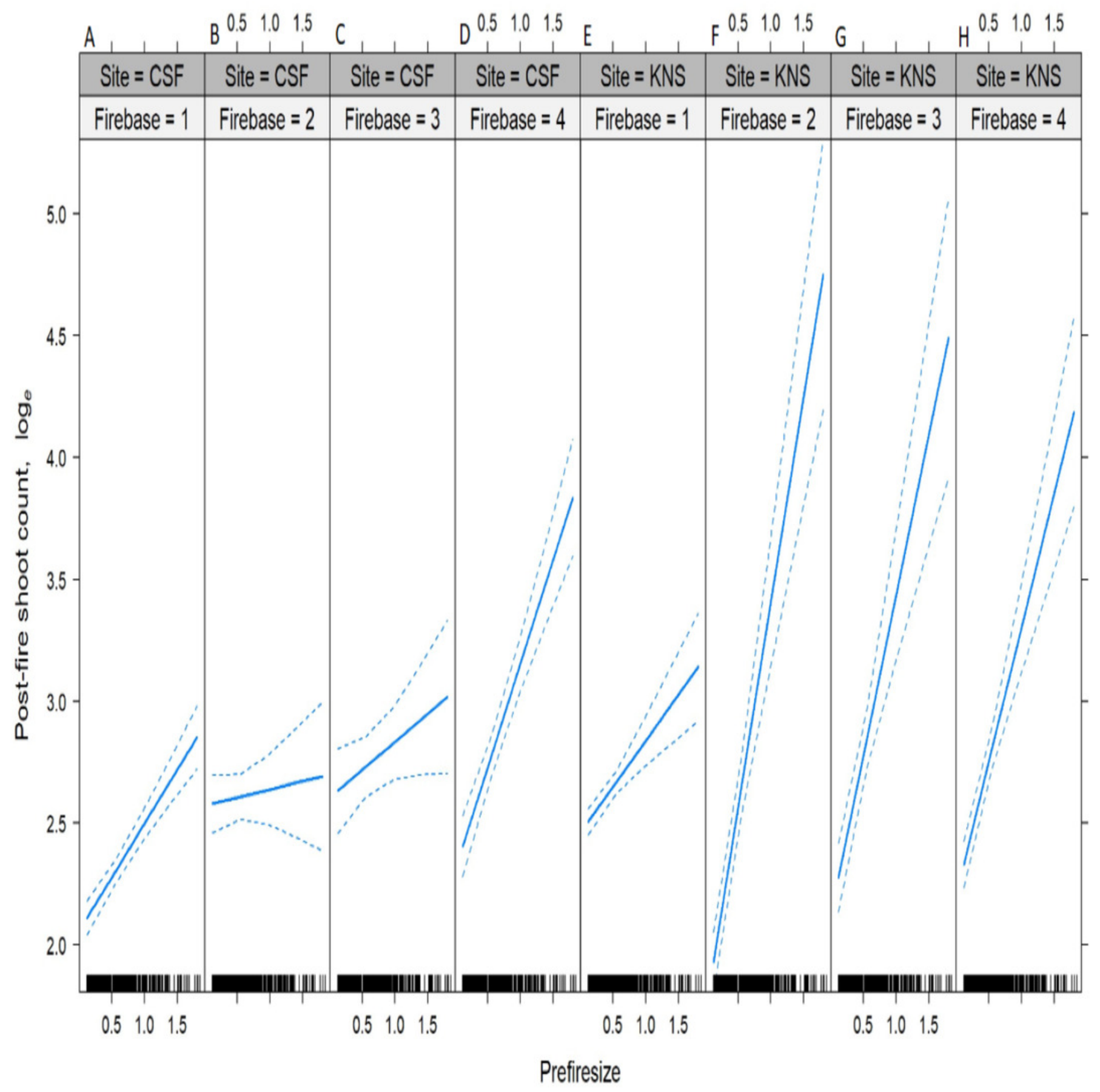


Figure 4

Predicted effects of the interactions between (A-B) pre-fire size and site, and (C-D) fire severity and site on the logarithm of post-fire resprouting volume of dune thicket shrubs

Fire severity was scored at the base of each shrub (Firebase $=1$, low; 2, medium; 3, high; 4, extreme). Pre-fire shrub size is an index (Prefiresize; see Methods for details). The output of the Weibull model that was used to calculate the effects is given in Table 4. 

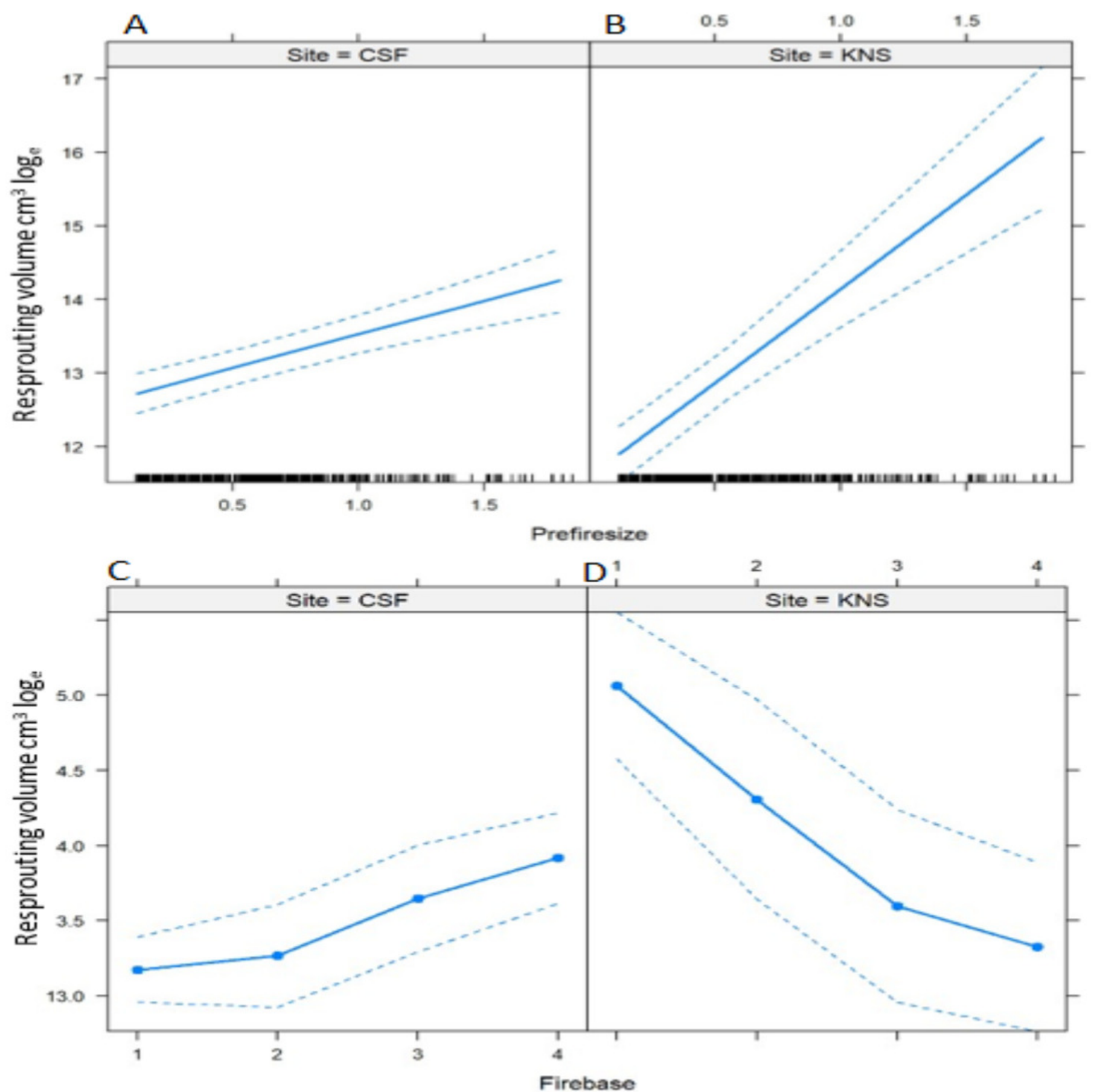


\section{Table $\mathbf{1}$ (on next page)}

Percentage survival, mean pre-fire size and sample number of thicket species surveyed at Cape St Francis (CSF) and Knysna (KNS).

Pre-fire size comprises an index calculated as the sum of pre-fire shrub lignotuber diameter and pre-fire stem count after both measures have been transformed to range between 0 and 1. 


\begin{tabular}{|c|c|c|c|c|c|c|}
\hline \multirow[b]{2}{*}{ Species } & \multicolumn{2}{|c|}{ Survival (\%) } & \multicolumn{2}{|c|}{$\begin{array}{l}\text { Mean } \\
\text { pre-fire size }\end{array}$} & \multicolumn{2}{|c|}{$\begin{array}{l}\text { Sample } \\
\text { number }\end{array}$} \\
\hline & CSF & KNS & CSF & KNS & $\mathrm{CSF}$ & KNS \\
\hline Acokanthera oppositifolia (Lam.) Codd & 100 & 100 & - & 0.26 & - & 1 \\
\hline Allophylus decipiens (Sond.) Radlk. & - & 92 & - & 0.17 & - & 13 \\
\hline Apodytes dimidiata E.Mey. ex Am. & - & 59 & - & 0.21 & - & 56 \\
\hline Buddleja saligna (Wild.) & - & 100 & & 0.29 & - & 8 \\
\hline Cassine peragua $\mathrm{L}$. & 100 & 79 & 0.41 & 0.36 & 21 & 58 \\
\hline Chionanthus foveolatus (E.Mey.) Stearn & - & 79 & - & 0.20 & - & 30 \\
\hline Clausena anisata (Wild.) Hook.f. ex Benth. & 100 & 100 & 0.25 & 0.23 & 15 & 11 \\
\hline Diospyros dichrophylla (Grand.) De Winter & - & 84 & - & 0.21 & - & 37 \\
\hline Dovyalis rhamnoides (Burch. ex DC.) Burch.and & 100 & 100 & 0.31 & 0.11 & 16 & 2 \\
\hline \multicolumn{7}{|l|}{ Harv. } \\
\hline Dovyalis rotundifolia (Thunb.) Thunb. and Harv. & 100 & - & 0.30 & - & 14 & - \\
\hline Euclea racemosa $\mathrm{L}$. & 92 & 92 & 0.30 & 0.21 & 39 & 13 \\
\hline Gymnosporia buxifolia (L.) Szyszyl. & 100 & 60 & 0.34 & 0.26 & 6 & 5 \\
\hline Gymnosporia nemorosa (Eckl. and Zeyh.) Szyszyl. & - & 90 & - & 0.32 & - & 12 \\
\hline Halleria lucida $\mathrm{L}$. & - & 100 & - & 0.17 & - & 2 \\
\hline Mystroxylon aethiopicum (Thunb.) Loes. & 86 & 100 & 0.54 & 0.29 & 97 & 10 \\
\hline Olea europaea subsp. africana $\mathrm{L}$. & - & 82 & - & 0.26 & - & 45 \\
\hline Olea exasperate Jacq. & 100 & 100 & 0.21 & 0.17 & 2 & 11 \\
\hline Osyris compressa (P.J.Bergius) & 100 & - & 0.62 & - & 2 & - \\
\hline Pittosporum viridiflorum Sims & - & 100 & - & 0.29 & - & 5 \\
\hline Psydrax obovata (Eckl. and Zeyh.) Bridson & 40 & - & 0.50 & - & 5 & - \\
\hline Pterocelastrus tricuspidatus (Lam.) Walp. & 90 & 80 & 0.80 & 0.42 & 136 & 141 \\
\hline Rapanaea melanophloeos (L.) Mez & - & 100 & - & 0.17 & - & 7 \\
\hline Scolopia zeyheri (Nees). Harv. & 100 & 51 & 0.25 & 0.22 & 2 & 39 \\
\hline Scutia myrtina (Burm.f.) Kurz & 100 & 100 & 0.31 & 0.14 & 28 & 3 \\
\hline Searsia glauca (Thunb.) Moffett & 81 & 80 & 0.46 & 0.24 & 108 & 20 \\
\hline Searsia lucida (L.) F.A Barkley & 100 & 87 & 0.50 & 0.31 & 49 & 55 \\
\hline
\end{tabular}


Sideroxylon inerme L.

Tarchonanthus littoralis P.P.J. Herman

Zanthoxylum capense (Thunb.) Harv.

All species collectively

$\begin{array}{llllll}76 & 71 & 0.51 & 0.44 & 97 & 78 \\ - & 100 & - & 0.37 & - & 80 \\ 79 & 83 & 0.42 & 0.13 & 14 & 6 \\ 85 & 83 & 0.41 & 0.51 & 519 & 593\end{array}$

1 


\section{Table 2 (on next page)}

Output of a logistic regression model (binomial family, logit link function) investigating the effects of fire severity, pre-fire size and site on post-fire thicket shrub survival.

Effects include fire severity scored at the base of each shrub (Firebase; orthogonal polynomial contrast trend test; L, linear; Q, quadratic; C, cubic), pre-fire size (Prefiresize; see Methods for details), site and fire severity $\mathrm{x}$ pre-fire size interaction. Models were fitted using treatment contrast with Cape St Francis as the reference level for site comparison with Knysna (KNS).

$*=p<0.05, * *=p<0.01, * * *=p<0.001$ 
Survival

(Intercept)

Firebase.L

Firebase.Q

Firebase.C

Prefiresize

SiteKNS

Firebase.L:Prefiresize

Firebase.Q:Prefiresize

Firebase.C:Prefiresize

Number of observations

Nagelkerke $\mathrm{R}^{2}$
Regression coefficients are log odds, standard errors in brackets

$1.28(0.23)^{* * *}$

$0.23(0.46)$

$0.66(0.38)$

$0.88(0.27)^{* *}$

$2.52(0.68)^{* * *}$

$-0.37(0.17)^{*}$

$-2.98(1.68)$

$-0.58(1.36)$

$-2.08(0.94)^{*}$

1398

0.05

1 


\section{Table 3 (on next page)}

Output of a Delaporte count model investigating the effects of fire severity, pre-fire size and site on thicket shrub resprouting shoot count.

Effects include fire severity scored at the base of each shrub (Firebase; orthogonal polynomial contrast trend test; L, linear; $Q$, quadratic; C, cubic), pre-fire size (Prefiresize), site, fire severity $\times$ pre-fire size interaction, fire severity $x$ site interaction, pre-fire size $x$ site interaction and fire severity $x$ pre-fire size $x$ site interactions. Coefficients for sigma and nu are for dispersion (variance), and skewness. Models were fitted using treatment contrasts with Cape St Francis as the reference level for Site comparison with Knysna (KNS).

$*=p<0.05, * *=p<0.01, * * *=p<0.001$ 
Resprouting shoot count

\begin{tabular}{|c|c|}
\hline Intercept) & $2.38(0.09)^{* * *}$ \\
\hline Firebase.L & $0.17(0.21)$ \\
\hline Firebase.Q & $-0.41(0.18)^{*}$ \\
\hline Firebase.C & $0.03(0.14)$ \\
\hline Prefiresize & $0.40(0.11)^{* * *}$ \\
\hline SiteKNS & $-0.26(0.12)^{*}$ \\
\hline Firebase.L:Prefiresize: & $0.31(0.25)$ \\
\hline Firebase.Q:Prefiresize: & $0.50(0.22)^{*}$ \\
\hline Firebase.C:Prefiresize: & $-0.02(0.19)$ \\
\hline Prefiresize:SiteKNS & $0.72(0.19)^{* * *}$ \\
\hline Firebase.L:SiteKNS & $-0.26(0.26)$ \\
\hline Firebase.Q:SiteKNS & $0.81(0.23)^{* * *}$ \\
\hline Firebase.C:SiteKNS & $-0.35(0.19)$ \\
\hline Firebase.L:Prefiresize:SiteKNS & $0.10(0.44)$ \\
\hline Firebase.Q:Prefiresize:SiteKNS & $-1.25(0.39)^{* *}$ \\
\hline Firebase.C:Prefiresize:SiteKNS & $0.42(0.34)$ \\
\hline sigma (Intercept) & $0.20(0.10)^{*}$ \\
\hline nu (Intercept) & $-1.36(0.13)^{* * *}$ \\
\hline Number of observations & 1112 \\
\hline Nagelkerke $\mathrm{R}^{2}$ & 0.09 \\
\hline
\end{tabular}

Regression coefficients are natural logarithms, standard errors are in brackets

$0.17(0.21)$

$-0.26(0.12)^{*}$

$0.31(0.25)$

$0.81(0.23)^{* * *}$

$-1.25(0.39)^{* *}$

$0.42(0.34)$

1112

0.09 


\section{Table 4(on next page)}

Output of a Weibull model investigating the effects of fire severity, pre-fire size and site on post-fire resprouting volume.

Effects include fire severity scored at the base of each shrub (Firebase; orthogonal polynomial contrast trend test; L, linear; Q, quadratic; C, cubic), pre-fire size (Prefiresize), site, fire severity $x$ site interaction and pre-fire size $x$ site interaction. Sigma represents the coefficient for dispersion (variance). Models were fitted using treatment contrasts with Cape St Francis as the reference level for Site comparison with Knysna (KNS).

$*=p<0.05, * *=p<0.01, * * *=p<0.001$ 
Resprouting volume

Regression coefficients are natural logarithms, standard errors are in brackets

\begin{tabular}{ll}
\hline Intercept) & $12.61(0.16)^{* * *}$ \\
Firebase.L & $0.58(0.22)^{* *}$ \\
Firebase.Q & $0.09(0.18)$ \\
Firebase.C & $-0.09(0.16)$ \\
Prefiresize & $0.91(0.22)^{* * *}$ \\
SiteKNS & $-1.03(0.21)^{* * *}$ \\
Firebase.L:SiteKNS & $-1.91(0.27)^{* * *}$ \\
Firebase.Q:SiteKNS & $0.15(0.23)$ \\
Firebase.C:SiteKNS & $0.18(0.20)$ \\
Prefiresize:SiteKNS & $1.65(0.38)^{* * *}$ \\
sigma (Intercept) & $-0.47(0.02)^{* * *}$ \\
Num. obs. & 1112 \\
Nagelkerke R 2 & 0.19 \\
\hline
\end{tabular}

1 